\title{
SCIENTIFIC KNOWLEDGE, PUBLIC KNOWLEDGE, AND PUBLIC POLICY: GENRED FORMATION AND DISRUPTION OF KNOWLEDGE FOR ACTING ABOUT GLOBAL WARMING
}

\author{
Charles Bazerman*
}

Abstract: Knowledge is produced, stored and accessed in specific genres associated with different activity systems. Coordinated action among diverse groups is facilitated by alignment of knowledge across spheres. Our knowledge of the environment has been created in recent history by the interaction of discourses in military, scientific, public, political, corporate and governmental spheres, although these spheres do not always work in concert and there exist significant obstacles and even resistances to communication of knowledge across boundaries. Citizen concerns have been crucial over the last sixty years in creating environmental knowledge from the perspective of citizens, in contrast to governmental or corporate interests, even though government has since taken on major responsibilities for the production, dissemination and authentication of environmental information. Those with a desire to disrupt remedial action on the environment have found disrupting the knowledge functions of the government an important tool.

Keywords: Genre. Knowledge. Environment. Politics. Government action.

\section{INTRODUCTION}

Cooperation on actions to mitigate global warming requires the committed engagement of people of many countries with many different interests. These interests arise out of the varied activity systems they are part of and from which they determine the value of policy and life choices. As many sacrifices and adjustments are likely to be necessary for concerted and effective action to mitigate global warming, many groups will have to recognize that an urgent problem exists, that the problem has certain characteristics, and that certain actions will likely be effective. Further they must agree that the situation is so dire and of such great

\footnotetext{
*University of California Santa Barbara. Email: bazerman@education.ucsb.edu.
} 
priority that they will be willing to undergo sacrifices of other valued goods and to make adjustments to well-established ways of life and business. This alignment over the existence, urgency, and solutions to global warming requires that each of these groups understand, trust, and accept the importance of a series of scientific findings, theories, and projections. To understand, trust, and accept this scientific work requires that they learn to engage with and make sense of Professional knowledges that have transformed our view of the environment, and more specifically climate. These knowledges are grounded within and get their evidentiary warrant from a specific set of citizen-oriented scientific genres and are disseminated and operationalized into public, government, and corporate action through other sets of genres. The problems and solutions to global warming are only identifiable and persuasive through the forms of evidence, calculation and reasoning existing in these genres. Insofar as people are not skilled in engaging with these genres they are not able to build trust and engagement with the solutions, even if they accept general propositions on authority. It is only through these genres that we know, and it is only when we know that we act with energy and conviction.

Climate change as a domain of knowledge provides a striking case of the way in which knowledge is produced, stored, accessed, and deliberated upon in specific genres developed for those purposes within specific social formations directed towards specific kinds of social activity. If the knowledge produced in the genres of one activity system bears on the genres and deliberations of other activity systems, specific work is required to bring the knowledge of one into another. What is known in one activity system is not immediately and automatically known in another, and individuals or groups with stakes in the deliberations of the receiving activity system may seek to control which knowledge enters into the new system and with what certitude, with consequences for decisions to be made upon that knowledge.

The phenomenon of global climate change itself cannot be directly and reliably experienced by any individual, nor is it even directly visible from the inspection of typical local weather records. Seeing climate change as a phenomenon, let alone recognizing that it poses a problem requires a specialized form of Professional vision (GOODWIN, 1994). It is a global process visible only in the scientific 
literature and literatures secondarily drawing in it, evidenced at first only through arguments from computer models, and only recently by aggregate planetary data (which still is given meaning by the models and the associated theories). An awareness that we have a problem is further dependent on models which project future conditions; additionally, a recognition that action is appropriate and possible is further dependent on scientific reasoning based on aggregation and calculation from further collections of data. The phenomenon and problem have gained widespread attention of scientific publics only in the last four decades, among citizenry and governments only in the last two, and most corporations only in the last decade. While there is high agreement in the scientific community and strong consensus that action is needed, there is somewhat less agreement and action consensus among citizens, even less focused will to cooperate among government, and only limited substantive engagement and cooperation among corporations. Our future hangs on gaining more thorough engagement with the scientifically based knowledge and its policy imperatives.

This essay is an attempt from a genre and activity theory perspective to understand that process of social learning and alignment to a set of technical knowledges. In this essay I will be bringing together the work of a number of my prior studies where the detailed evidence and analysis are available (BAZERMAN, 2001; BAZERMAN, LITTLE, CHAVKIN, 2003; BAZERMAN; DE LOS SANTOS, 2005). These studies are based predominantly on events and evidence from the United States, but given the U.S. role in science and international cooperation, the harnessing of US political will is an important element in global negotiations. Thus this story is of more than local interest. Nonetheless, because cooperation of people and organizations in every nation is essential for effective global cooperation dictates we need to have similar studies or understandings of the formation of politics and policy in each nation and region. My hope is that the studies synthesized here and similar studies by others will contributes to understanding the challenge in front of us as literacy educators and public rhetoricians. I further hope the argument here will help illuminate how policy, politics, and concerted action are tied to regimes of knowledge embodied in texts. 


\section{KNOWLEDGE RESIDES WITHIN GENRES}

Theoretically, the grounds of these studies are that knowledge is inscribed, reasoned about, stored, and accessed in specific genres in which they are chronotopically appropriate. Bakhtin noted that each genre was associated with a specific time and space, or chronotope, that was populated by expected types of characters, objects, scenery and other elements, which then were part of an expected set of unfolding of events (BAKHTIN, 1981). Some genres in fact exist with the specific aim of producing, warranting, evaluating, or distributing specific forms of knowledge (BAZERMAN, 1999). Engaged and knowledgeable participants in various activity systems know where relevant knowledges are to be found. This is an extension of the observation that most of what we consider knowledge is embodied in linguistically produced artifacts, typically in a written, rather than purely spoken form. These knowledges are produced, warranted, and used by particular groupings of people who are bound together by series of publications and other related communicative forums in which the typical genres of the groups are produced, rehearsed, and discussed (BAZERMAN; ROGERS, 2008). Further productions are intertextually linked to prior texts and the knowledges produced therein. Evidence, including empirical evidence gathered from outside the textual world, must be gathered and inscribed by methods and forms that are warrantable and accepted, if not typical, of the social groupings - and then displayed within appropriate genres, both for evaluation and as warranted for further knowledge claims. This production, collection, and mutual articulation of knowledges and evidence within disciplinary or professional domains within appropriate forms allows for cooperation in the production of shared knowledge and the forging of areas of agreement, creating the basis of coordinated future action.

Further, with relevance to issues such as global warming, involving cooperation across many groups of people, it is important that knowledge be brought from one sphere of coordinated knowledge to another. This is a consequence of the fact that different communicative spaces--particular genres within particular activity systems gain the attention and belief of different groups of people, and knowledge does not readily flow from one to another. For example, the rules and 
purposes of evidence within the law are very different than those of science, and if scientific knowledges bear on a court case, there are elaborate procedures for carrying information across the boundaries which in fact transform the nature and particulars of the knowledge as well as their operational effect, often leaving scientists unhappy with what knowledge gets to the courts (see BAZERMAN, 2009). Thus large group actions involving many people in many different roles and configurations must somehow coordinate their knowledges so as to carry out commitments to a related view of the problem to be addressed; otherwise, the groups will not be able to act with clarity, conviction, and commitment.

\section{KNOWING THE ENVIRONMENT}

So how do we know the environment? While we may walk through forests and enjoy the sounds of birds, and while environmental phenomenon may affect what we see and hear and feel on our walks, when we talk of the environment we are more likely to have in mind things we have read - in public media that drew on specific scientific literatures. Indeed until recent decades we would not even be likely to refer to ambient nature as an environment, let alone to perceive what we see on our walks as an interdependent system. Even among scientists the concepts of environment and ecosystem were inventions of the midnineteenth century and remained of limited attention and interest until the latter half of the twentieth, circulating only in a limited set of genres within the some biological specializations. Few scientists, let alone policy makers or citizens, had reason to turn to the pages of journals where the concept resided.

Within the U.S. public sphere, attending to our ambient world as the environment and seeing it as problematic or threatened by human action are associated most early with Rachel Carson and the scattered scientists she drew on, pointing to the problems created by DDT and other pesticides. (Earlier concerns about pollution, such as air pollution from industrial and vehicle emissions were seen more as a traditional matter of direct contamination.) Carson herself was a government naturalist, who had written a number of popular books of nature appreciation. In writing Silent Spring, she drew on these as well as several 
other available public genres, including the social problem essay and dystopic science fiction to create a compelling public account that changed public ways of viewing their actions as potential having longterm systemic consequences on the conditions of our life as ramified through complex interdependent processes (see WADDELL, 2000 for useful contexts and analyses of Carson's book). The wide circulation of Silent Spring created political and policy discussions which led to government regulation of pesticides. This new line of environmental legislation, though having characteristics of earlier food and drug regulation, had a substantially different character, regulating small amounts of chemicals that would have long range aggregate consequences. This kind of reasoning and the needs of associated regulation also gave rise to new scientific specialties such as ecotoxicology that statistically calculated long term results under field conditions in contrast to the controlled laboratory experiments of traditional toxicology (see BAZERMAN; DE LOS SANTOS, 2005 for a study of the divisions and reconciliations that impeded and eventually allowed evidence to travel between genres of these fields). We can also see the continuing effect of the communicative model she created in the introductory comments of Al Gore to the 1995 reissue of Silent Spring, indicating the direct genre genealogy of Earth in the Balance (GORE, 1992).

For me personally, Silent Spring had a profound impact. It was one of the books we read at home at my mother's insistence and then discussed around the dinner table. My sister and I didn't like every book that made it to that table, but our conversations about Silent Spring are a happy and vivid memory. Indeed, Rachel Carson was one of the reasons I became so conscious of the environment and so involved with environmental issues. Her example inspired me to write Earth in the Balance, which, not coincidentally, was published by Houghton Mifflin, the company that stood by Carson through all the controversy and that has since earned a reputation for publishing many fine books about the environmental dangers facing our world. (GORE introduction to CARSON, 1995) 
Concurrently another set of events was creating a related set of genres at the intersection of science, public issues, and government policy. We can pick up this story with the Manhattan Project, which developed the atom bomb under conditions of the highest secrecy. Under the exigencies of WWII, academic science, which had been used to the free flow of information, acquiesced to military disciplines of restricted flow of knowledge. After the Hiroshima and Nagasaki atomic detonations and the end of the war, scientists exerted pressure to allow open access to the scientific findings. Advocates of civilian monitoring and democratic decision making also wanted the science to be publicly available. The rapid emergence of the Cold War created new pressures for secrecy, so that major restrictions remained (monitored by the newlyformed Atomic Energy Commission) keeping much of the knowledge about nuclear weaponry and its effects within classified military documents. However less than a decade later, after atmospheric testing of hydrogen weapons posed threats of radiation fallout, public pressure increased for more detailed information about the effects of fallout, particularly strontium 90 . Strontium 90 was chemically similar to calcium, thus fallout onto grasslands were ingested by cows and concentrated in milk, Children who would drink the milk from contaminated cows would then concentrate the strontium 90 in their bones and teeth.

After government and military sources remained vague on details despite public pressure, an alliance between academic scientists and citizen groups formed in St Louis to make knowledge available and pressure for limiting testing and the associated nuclear fallout. The St. Louis Citizens' Committee for Nuclear information began producing newsletters called Information, then Nuclear Information. Those newsletters provided scientific knowledge from the perspective of public problems, though presenting the political message only by implication. The selection and organization of the texts, nonetheless, clearly made evident governmental actions were putting citizens at threat by disrupting the safe environment for human life. The organizers of this movement were self-conscious about advancing citizen science in the public interest, gathered by scientists who considered themselves as citizens in their loyalties, rather than being in the employ of government, military or industry. Such scientists would develop their research questions from 
public need rather than internal dynamics of science. The direct linkage between this movement and the environmental movement is indicated by the name changes of the newsletter as it transformed into a journal. Nuclear Information became retitled Scientist and Citizen and then Environment. Even as the articles became more technical they kept the focus on public problems (BAZERMAN, 2001).

The increasing public concern for the environment became a major political issue to which Congress responded with the National Environmental Policy Act of 1970. In the discussion leading up to the passage of the act a repeated theme was the lack of information available on which to base policy, so a chief provision was to require an Environmental Impact Statement be produced for any government action that might affect the environment. In addition to creating a new genre by fiat (the success of which has been controversial both within the environmental and the genre community), this added to the textual vehicles that would require monitoring of actions from the citizen's perspective and expand the market for the production of such information. Further it would identify governmental agencies as responsible parties for the collection of such information, taking some of the impetus away from grassroots citizen groups (BAZERMAN; LITTLE; CHAVKIN, 2003).

So in less than a twenty year period we had new communicative channels that fostered public attention and access to certain kinds of scientific information viewed as relevant for public well-being, particularly because normal conditions of life were under threat by human actions. These new communicative channels created a market for scientists who would adopt a public interest perspective. These channels in turn fostered new developments within the more purely scientific community and in the more fully political communities.

\section{KNOWING ABOUT GLOBAL WARMING}

Among the issues that inhabited this new communicative space was global warming. Awareness of global warning also began in military sponsored science. While the concept of greenhouse warming of the atmosphere was first proposed by Fourier in the 1820's and revived by an engineer Callendar in 1850, it was paid little attention to, and there 
was little evidence to suggest its occurrence, until the 1950's. Military interests in the Cold War period led to monitoring of the oceans and atmosphere as potential sites of military engagement. Working for the Office of Naval Research, in 1957 Roger Revelle noted that recorded ocean uptake of excess $\mathrm{CO} 2$ was less than anticipated, which meant that atmospheric $\mathrm{CO} 2$ produced by hydrocarbon combustion would be increasing (WEART, 2003, 2008). In the 1960's to track this and similar data the National Center for Atmospheric Research was founded (WEART, 2003, 2008). In 1970 this agency was reorganized as the National Oceanic \& Atmospheric Administration (NOAA) under the Department of Commerce. Most of the foundational research on global warming at that time and since has been done by governmental agencies or under related government funding, often tied to national security concerns, though increasingly with attention to the disruption of everyday life of citizens here and elsewhere. James Hansen, perhaps the leading figure in global warming science, has been employed at the NASA Goddard Institute for Space Studies in New York City since 1972 and has been its director since 1981. NASA, although an independent government agency has been from its founding deeply intertwined with military interests, although increasingly addressing concerns of more general citizenry.

Much of the global warming research has been based on computer models of global and regional climates, with historic data and projections forward, looking not only to climate impacts and turbulence, but as well on impacts on sea level, agriculture, and other climate sensitive phenomena. Such models always have a degree of speculation, extrapolation, and simplification so authoritativeness and certainty was an issue from the beginning, with many competing models and projections, using both different data collections and different algorithms. Nonetheless, the results were alarming enough that by the mid 1980's increasing numbers of reports appeared about the potentials (see www.globalwarmingarchive.com/Timeline.aspx). In particular governmental reports from the Environmental Protection Agency in 1983 made public concerns that global warming would begin to be evident in the 1990's with serious consequences for food production and sea levels The New York Times article describing this report had to provide not only an introduction to the scientific principles of greenhouse 
warming, and a survey of the evidence, but also a discussion of the nature of the computational models with their uncertainties (SHABECOFF, 1983). The public needed to be educated into the scientific issues and given a primer or atmospheric science in order to understand the issue, evidence, and specialized form of argument.

The EPA report indicated that by 1983 there was already strong consensus among scientists that serious global warming would be occurring because of human produced carbon dioxide, though there were some differences on timing and severity. A series of UN sponsored scientific panels also tracked the solidifying scientific consensus. In 1988 World Meteorological Organization and UN Environment Programme formed the Intergovernmental Panel on Climate Change (IPCC) (www.ipcc.ch). The first assessment report of the IPCC in 1990 expressed some differences and uncertainties about the specific scenarios that might unfold, but confirmed the importance of the issue and established a framework for addressing the climate change issue and gathering data for future reports. The second assessment report in 1995 presented confidence on the existence and magnitude of global warming and offered specific projections. This report formed the framework for deliberations of the Kyoto Protocol in 1997. The third assessment in 2001 presented strong evidence that change had already occurred, considered the mechanisms of the change, and offered options for action to intervene in the mechanisms. The fourth assessment in 2007 noted the substantial effects that had already occurred and will be continuing, and offered scenarios that might mitigate the consequences. The fifth Assessment report is to be finalized in 2014.

\section{KNOWLEDGE FOR POLICY ACTION}

It is quite unusual for adjudication panels to be formed in science, as codification of knowledge is usually left of implicit processes of review, citation, and incorporation into future work, reviews, and textbooks (BAZERMAN, 1991). The EPA and IPCC reports, based on panel judgments and circulation among wide numbers of scientists for their approval, indicate firstly the intersection with policy and public concerns and secondly that governmental action and intergovernmental cooperation require a high degree of sharing of knowledge considered 
authoritative and trustworthy. A citation account or review of the literature is not an adequate sign of scientific agreement for governmental policy action. Rather a governmentally or intergovernmentally authorized body must authenticate findings with the explicit comment of a wide sample of the authoritative scientists in the area. But scientific consensus, even government authorized adjudication of consensus, is not enough for concerted action. The knowledge needs to gain the belief and commitment of segments of the population and institutional groups who will have to cooperate with the action. This brings in another level of complication.

We had already seen the formation of citizen engagement with environmental knowledge initiated by activist groups but extended through journalism, specialized reports, and non-fiction public problem policy books. These vehicles had made accessible knowledge of global warming early and there had been developing by the 1990's substantial public consensus that global warming was occurring.

By 1992 68\% of the U.S. public believed that global warming was real as a phenomenon - a number that despite a dip in 1994 - has since only increased to around $75 \%$ with fewer than $20 \%$ skeptical. More recent polls also indicate that a strong majority (around 60\% believe the effects are already being seen). Curiously, however beliefs about scientific certainty lagged behind with $28 \%$ of the sampled public believing that there was scientific certainty in 1994, $46 \%$ percent in 1997 $61 \%$ in 2001 and $65 \%$ in 2006. The bulk of the other responders, however, rather than exhibiting belief that scientists were not convinced rather stated they were unsure (58\% in 1994, $37 \%$ in 1997, 30\% in 1991, and $29 \%$ in 2006 . This indicates that the overwhelming certainty among scientists, expressed in the 1983 EPA and 1995 IPCC reports was not being communicated clearly to segments of the public, even though awareness of the phenomenon had. In 1994 there was a 29\% disparity between citizens' own certainty and their estimate of scientific certainty, $21 \%$ in $1997,16 \%$ in 2001, and perhaps $10 \%$ more recently though it is hard to gauge because of changes in the questions (NISBET; MYERS, 2007).

Government under the Clinton administration also expressed strong alignment with knowledge about global warming, as expressed in reports, websites and other documents, as did Congressional Office of 
Technology Assessment reports in the early 1990's. The Clinton Administration was also active in negotiating and supporting the Kyoto protocols in 1997. Vice President Al Gore was active in many environmental initiatives as well as advocating for the Kyoto Protocol.

\section{INTERFERING WITH WHAT PUBLICS AND GOVERNMENTS KNOW}

Republican control of Congress in 1994 and the Bush presidency in 2001 changed the stance branches of government and their role in the knowledge process, following the interests of the corporate sector, which resisted the emerging consensus about global warming and did its best to disrupt communication and alignment among the other three sectors. In particular the corporate sector used their influence on the government sector increased their ability to disrupt alignment of knowledge - this is the story behind the Republican Congressional opposition in the 1990s, the Bush positions, and the curious anomalies in the public perception of science.

But before we go into the specifics of the activities of the corporate sector, particularly the energy sector, we need to look at the underlying causes of the stance they take toward the environment from a genre and knowledge perspective. Businesses typically have a short to middle range time horizon on making financial decisions to enhance profitability and growth in the foreseeable future, usually at most three to five years. The uncertainty of long and even middle range economic forecasting also mitigates against longer planning. What planning does occur has to rely on historic conditions and trends. Thus the genres that collect knowledge for decision making and then attempt to extrapolate forward chronotopically consider the future much like the past. Projections into the future beyond the immediate upcoming quarters and years fade from view, particularly futures that might incorporate radical changes in conditions. In publicly held companies, maintaining or increasing stock prices through growth of quarter to quarter profits keeps calculations even more in the near term, as any quick scan of stock analyses will indicate. This short time frame has been further tightened by the tying of executive compensation to stock prices through options and bonuses. In this short to middle time frame, global warming does 
not turn up in any serious way on the past or projected balance sheets and thus does not seriously enter into the calculations. Losses through extreme weather and other natural disasters are covered by insurance, and at worst, increased risk of climate induced disasters turns up as increased casualty insurance premiums - in most industries not a significant cost compared to sales and other expenses. It is only when predictable changes in sales might occur as a result of consumer needs and desires or production costs might change in light of climate change would climate really be worth taking into account. Government regulation and other mandated adjustments might influence consumer behavior and would be a greater pressure on the business model, and thus concerted action on climate change would be more of a threat to projected profitability (the core goal in corporate economic planning) than direct loss from global warming.

The insurance industry, however, has for centuries had a longer time frame for data gathering and planning. Accordingly, it has developed genres for displaying the long time frame and calculating profit within it. Since its business is built on balancing current income against rarely occurring events, the insurance industry since the seventeenth century has been developing actuarial tools of determining long-term costs and risks and matching that to current income and profitability. Even more directly, climate-induced disasters incur direct business expenses and cannot be laid of to anyone, except maybe the large reinsurers. Therefore, it is quite understandable that insurance, with the reinsurers leading the way, was the first industry to recommend action on global warming. By early 1990's some European insurers, became concerned with global warming's impact on their industry (MOLLIN, 1993). Large reinsurers such as Munich Reinsurance Company hired their own meteorologists and climatologists to prepare internal reports (MILLS, 1998). Indeed the industry began eco-friendly insurance products that encouraged eco-friendy behavior, and began basing investments on environmental and sustainability audits (HOEPPE; BERZ, 2005).

But for most industries, action to mitigate global warming calculated more negatively than the costs created by warming itself. Global Warming action might even require fundamental restructuring of industry and restriction on business. The oil, coal, and electrical power 
industries began to pay worried attention to predictions about global warming as early as the late 1970s before any substantial public, political, or public policy awareness had emerged. But enough significant scientific knowledge was already emerging which was soon to gain activist, political and even government attention, so it was not feasible simply to suppress this information and keep it out of the public and governmental sphere. Rather certain segments of industry, particular the energy sector, adopted a strategy to disrupt the confidence and direction of the emerging public discussion of what, if anything, needed to be done. This tactic, recently called agnotology (PROCTOR; SCHIEBINGER, 2008, see also MICHAELS, 2008) - the active production of uncertainty - was first developed by the tobacco lobby to maintain the appearance of "controversy" which undermined our sense of knowledge with its imperative for action. The strategy was carried out by producing the appearance of scientific disagreement through magnification of minor differences and the sponsored production of legitimate seeming but rather questionable research that appeared to contradict more independent and solid work. Then on the basis of this manufactured appearance of uncertainty, lobbies could argue for more research, delays in action, or simply against action which might appear as an expensive and unnecessary gamble.

One of the key organizations for this production of disruptive knowledge about global warming became the George C. Marshall Institute, which had previously been engaged in arguing for Reagan's strategic Defense Initiative, known as Star Wars. Interestingly two of the key players in this organization as it turned its attention to energy had long experience with the production of quasi science for the tobacco lobby. S. Frederick Seitz, chair of the Marshall Institute, was a consultant to tobacco company RJ Reynolds until 1989. S. Fred Singer who authored 35 articles and books questioning Global Warming under the sponsorship of the Institute had also learned this strategy through tobacco research (ORESKES; CONWAY, 2008). As part of the same strategy, after the negotiation of the Kyoto accord, The "Cooler Heads Coalition" was funded by Exxon Mobil to argue against US ratification.

The energy lobby found its allies in the political sphere where they brought the knowledge disruption tactics first to Congress and then to the Bush administration, so government deliberations also could not be 
carried out in an atmosphere of scientific certainty. Frank Luntz a chief Republican political strategist in a 1992 memo urged that the Republicans "make the lack of scientific certainty a primary issue." Republican Senator James Inhofe, who became chair of the Senate committee on Environment and Public Works when the Republicans gained the majority in Congress in 1994 called global warming a fraud and organized hearings to make that case. Among the witnesses he called was Michael Crichton, a science fiction and suspense writer. When George W. Bush became president, his administration almost immediately announced it would not implement the Kyoto Protocol. Further the White house then began to participate in the disruption of public certainty about scientific knowledge. Previous reports were expunged from the EPA website, and new scientific reports were edited by a lawyer Philip Cooney who had previously been a lobbyist for the American Petroleum Institute. His handiwork typically involved adding words such as perhaps, maybe, or uncertainty at key locations in scientific reports which had originally been drafted with full certainty. The US National Assessment on Climate Change, mandated by the UN, was very quiet about global warming. The 600 page draft of the 2003 report had only six paragraphs on global warming; the White House then deleted five and added a reference to an ExxonMobil-funded study disputing the global warming hypothesis. So as to further disrupt the flow of substantial scientific information, James Hansen, still head of the Goddard Institute, was ordered not to speak publicly on global warming issues.

A change of administration in 2008 has once again brought about a realignment with scientific knowledge, with which government reports, websites and proposals are now acting in consonance. We now are currently in the middle of legislative deliberations to address the recognized problem and to foster engagement with other nations to achieve global cooperation. That is good news. Nonetheless, the history of production of knowledge about the environment and global warming along with the recent adventure into agnotology suggest that we are not done with seeing attempts to disrupt public and governmental certainty about knowledge which already has strong scientific consensus. 


\section{FINAL COMMENTS}

This episode highlights how certainty of knowledge comes about through coordinated information within key knowledge genres in each sphere, how certainty expressed in the genres of one sphere does not necessarily translate into certainty of knowledge in others, how alignment of knowledge across the genres of different spheres is necessary for coordinated action on complex matters, and disruption of the knowledge translation problem can be disruptive of action. With respect to the environment this case has highlighted the centrality of science as a producer of authoritative knowledge, the necessity and difficulty of getting other spheres to attend to it and understand it to incorporate the findings into its reasoning, and the power of disrupting that process of shared knowledge construction and deliberation. Further, this case has highlighted the role of the federal government within the US system as a central gatherer, authorizer, disseminator, and site of action calculation within certain kinds of policy matters of which global warming is a major example. Even when science and the public remain convinced, and the disruptive insertion of distracting claims and inappropriate doubts is transparently obvious to all players, the deliberative process is thrown into sufficient confusion and uncertainty of calculation so that action can be stopped. Not only were the internal deliberations of the U.S. government stalled, but major obstacles were placed on international negotiations.

Finally, while the national government plays such a central role in the production, sponsorship, authentication, and dissemination of knowledge as well as its direct use for deliberation on action, we should remember that all governments are beholden to many forces and pressures. While the U.S. government took on some responsibility for citizen's need for knowledge and action, citizens as citizens are not its only client. Actions in the name of citizens can often be betrayed or hijacked by other interests, so that citizens must maintain citizen genres of knowledge production and evaluation of knowledge from other spheres. It must then monitor government knowledge and actions within certain genres of inspection and evaluation, and must mount political pressure through its various communicative genres to hold the government to its responsibility for maintaining and acting on solid science in the public interest. 


\section{REFERENCES}

BAKHTIN, M.M. The dialogic imagination. Austin: University of Texas Press, 1981.

BAZERMAN, C. How natural philosophers can cooperate: the rhetorical technology of coordinated research in Joseph Priestley's History and present state of electricity. In: BAZERMAN, C.; PARADIS, P. (Eds.) Textual dynamics of the professions. Madison: University of Wisconsin, 1991. p. 13-44.

. Singular utterances: realizing local activities through typified forms in typified circumstances. In: TROSBERG, A. (Ed.) Analysing the discourses of professional genres. Amsterdam: Benjamins, 1999. p. 25-40.

. Nuclear information: One rhetorical moment in the construction of the information age. Written Communication, v. 18, n. 3, p. 259-295, 2001.

. How does science come to speak in the courts? Citations, intertexts, expert witnesses, consequential facts and reasoning. Law and Contemporary Problems, v. 72, n. 1, p. 91-120, 2009.

BAZERMAN, C.; DE LOS SANTOS, R. Measuring Incommensurability: are toxicology and ecotoxicology blind to what the other sees? In: HARRIS, R. (Ed.) Rhetoric and incommensurability. West Lafayette: Parlor, 2005. p. 424-463.

BAZERMAN, C., LITTLE, J.; CHAVKIN, T. The production of information for genred activity spaces. Written Communication, v. 20, n. 4, p. 455-477, 2003.

BAZERMAN, C.; ROGERS, P. Writing and secular knowledge apart from modern European institutions \& Writing and secular knowledge within modern European institutions. In: BAZERMAN, C. (Ed.) Handbook of research on writing. Routledge, 2008. p. 143-176.

CARSON, R. Silent Spring. Boston: Houghton Mifflin, 1995 [1962].

GOODWIN, C. Professional vision. American Anthropologist, v. 96, n. 3, p. 606-633, 1994.

GORE, A. Earth in the balance: ecology and the human spirit. Boston: Houghton Mifflin, 1992. 
HOEPPE, P.; BERZ, G. Risks of climate change-the perspective of the (reinsurance) industry. POWER ENGINEERING SOCIETY GENERAL MEETING, IEEE. Proceedings..., p. 1367-1370, 2005.

MICHAELS, D. Doubt is their product. Oxford: Oxford University, 2008.

MILLS, E. The coming storm: global warming and risk management. Risk Management, v. 45, n. 5, p. 20-25, 1998.

MOLLIN, H. Will global warming cool off weather underwriting? Risk Management, v. 40, n. 3, p. 28-35, 1993.

NISBET, M. C.; MYERS, T. Twenty years of public opinion about global warming. Public Opinion Quarterly, v. 71, n. 3, p. 444-470, 2007.

ORESKES, N.; CONWAY, E. Challenging knowledge. In: PROCTOR, P. ; SCHIEBINGER, L. (Eds.) Agnotology: the making \& unmaking of ignorance. Palo Alto: Stanford, 2008. p. 55-89.

PROCTOR, R. N.; SCHIEBINGER, L. (Eds.) Agnotology: the making \& unmaking of ignorance. Palo Alto: Stanford, 2008.

SHABECOFF, P. E. p. A. Report says Earth will heat up beginning in 1990's. New York Times, Oct 18, 1983. p. 1.

WADDELL, C. (Ed.) And no birds sing: rhetorical analyses of Silent spring. Carbondale: Southern Illinois University, 2000.

WEART, S. The discovery of global warming. Harvard, 2003, 2008. Available at: <http://www.aip.org/history/climate/>.

Recebido em 30/08/2010. Aprovado em 25/11/2010.

Título: Conhecimento científico, conbecimento público e política pública: Formação genérica e quebra de conbecimento na ação contra o aquecimento global

Autor: Charles Bazerman

Resumo: O conbecimento é produzido, guardado e acessado através de gêneros específicos, associados a diferentes sistemas de atividades. A ação coordenada entre diversos grupos é facilitada pelo alinhamento do conhecimento através de esferas. Nosso conbecimento sobre o ambiente foi criado na história recente através da interação de discursos nas esferas militar, cientifica, pública, política, corporativa e governamental, embora tais esferas nem sempre funcionem em acordo, e existam importante obstáculos e mesmo resistência a se transmitir o conhecimento através dos limites entre as esferas. As preocupações dos cidadãos têm sido cruciais, nestes últimos sessenta anos, para a criação de conbecimento sobre o meio ambiente a partir da perspectiva dos próprios cidadãos, em contraste com os interesses governamentais e corporativos, mesmo se o governo vem assumindo importantes responsabilidades na produção, 
disseminação e validação da informação ambiental. Aqueles que desejam romper com a ação que apenas vem remediar estragos feitos no meio ambiente descobriram que modificar as funções de conbecimento do governo constitui uma importante ferramenta.

Palavras-chave: Gênero. Conhecimento. Ambiente. Política. Ação governamental.

Título: Conocimiento científico, conocimiento público, y política de interés público: Formación genérica y ruptura del conocimiento para actuar sobre el calentamiento global

Autor: Charles Bazerman

Resumen: El conocimiento es producido, guardado y accesado a través de géneros específicos, asociados a diferentes sistemas de actividades. La acción coordinada entre diversos grupos es facilitada por el alineamiento del conocimiento a través de esferas. Nuestro conocimiento sobre el ambiente fue creado en la historia reciente a través de la interacción de discursos en las esferas militar, cientifica, pública, política, corporativa y gubernamental, aunque tales esferas ni siempre funcionen en acuerdo, y existan importante obstáculos y aun resistencia a transmitir el conocimiento a través de los límites entre las esferas. Las preocupaciones de los ciudadanos han sido cruciales, en estos últimos sesenta años, para la creación de conocimiento sobre el medio ambiente a partir de la perspectiva de los propios ciudadanos, en contraste con los intereses gubernamentales y corporativos, aun si el gobierno viene asumiendo importantes responsabilidades en la producción, diseminación y validación de la información ambiental. Aquellos que desean romper con la acción que apenas viene a remediar males bechos al medio ambiente descubrieron que modificar las funciones de conocimiento del gobierno constituye una importante herramienta.

Palabras-clave: Género. Conocimiento. Ambiente. Política. Acción gubernamental. 